\title{
"A Comparative Study of Budgeted Expenditure and Actual Expenditure in Relation to Haryana Budget"
}

\author{
Ritesh Kalra ${ }^{1}$, Tejaswini ${ }^{2}$ \\ ${ }^{I}$ (Research Scholar, University School of Management, Kurukshetra University, Kurukshetra) \\ 2(M.com Student, MCM DAV College, Chandigarh)
}

\begin{abstract}
Controlling over the Expenditure is the most important objective of any budget. The Budget which focuses only on revenue generation and not on expenditure controlling cannot perform up to the expectation of the society. The efficiency of controlling in expenditure can be analyse by comparing the Budgets and Actuals after the actual are realised. The present study also aims to find out the efficiency of Haryana Budget in relation to controlling the expenditures. The study makes a comparison of Budgeted and Actual Expenditure provided in the Haryana Budget. The study considers plan and non plan expenditure, also revenue and capital expenditure. The data has been taken for eight years from 2006-07 to 2013-14. The data is taken from the website of Department of Finance, Government of Haryana. The data has been analysed by using many statistical tool such as mean, standard deviation and independent t-test (two samples). The statistical results shows that there is no significant difference between Budgeted and Actual Expenditure whether Non Plan, Plan, Revenue Expenditure or Capital Expenditure.
\end{abstract}

Key Words: Budgeted \& Actual Expenditure, Plan \& Non plan Expenditure, Revenue \& Capital Expenditure.

\section{INTRODUCTION}

Public Budget is a government's policy documents explaining the source and application of fund in the near future. Government collects resources from the Environment and uses these resources for the welfare of the society. The government has natural resources and the taxation system for the generation of revenue and it has to incur the expenses for the welfare of the society. Thus Budget is important aspect which carry the relationship between revenue and the expenditure that reflect the expectation of the society.

Initially the Public Budgets were considered just as plan for the public expenditure and public revenue. But now days the role of public budget has been increased a lot. "Our Government does not view the Budget as a mere exercise of presenting the statement of Government receipts and expenditure of a given year. It is rather an expression of our vision of economic strategy and an instrument of social development, change and inclusion." [1]. Thus now it is considered as policy document providing different policies for the people involved in different professions, business and employment etc. However the main objective of the public budget is still to balance the fiscal deficit by balancing the public revenue and public expenditure. Thus the role of Revenue and Expenditure is most important and most Crucial in any Public Budget. In the past we have seen that all government bodies has given the importance to generating more and more revenues by putting various taxes with different slabs and rates of taxes on the common man and no control has been exercise on the public expenditure. But recently we saw some step were taken by different governments to control the public expenditure such as using economic class in flight, reducing VIP culture, avoiding expensive vehicle etc. But these steps are not significant to controlling public expenditure. For controlling public expenditure the government must efficiently plan their expenditure before allocating these expenditures to its sub bodies. Not only this but the government must also have some tracing system to control and check that the expenditure allocated must use for the same purposes for which these has been granted. Further the government should compare the actual to the budget in order to find deviation and their reasons. Then only we will be able to have control over the expenditures.

Further the biggest challenge of any Budget (whether public or private) is to achieve efficiency that means the Budget Estimates which are forecast before the year for the upcoming year must be reliable. As the Budget is always related to the future which is uncertain thus it never can be forecast with 100 per cent accuracy but it is always expected to have some good amount of accuracy otherwise the role of Public Budgets will be nil. This study 
also compares the different budgeted expenditure to actual expenditure of Haryana Budget in order to find out the accuracy of Haryana Budget in terms of expenditure forecasting.

\section{REVIEW OF LITERATURE}

The study [2] analysis the role of expenditure which has occurred to pay as salary and remuneration for those time in which work has not carried out in the public sector. The study takes the data belonging to California from 1974 to 1984. It takes several factors such as Vacation, sick leave, Tea Break, Meal Period, Training, Maternity Leave, Time off For Union Business/ Strikes etc and their cost in the total expenditure. It finds that due to collective bargaining and negotiation the Cost for the Time Not Worked has increased. During the study period i.e. from 1974 to 1984 this cost has recorded increase up to $121 \%$ in the private sector while the salaries has increased to $115 \%$ however in the Public Sector it has increase up to $215 \%$ while the salaries has increased $98 \%$ in the same. Thus pay for time not worked has increased dramatically in the public sector which also reflects the total expenditure in the public budget.

The study [3] attempts to explain that how the Generational Accounts can replace Public Budget and Deficit. The study defines Generational Accounts as "tabulation of the net effect of future taxes paid and transfer receive by various generations, assuming that current policy remain unchanged in to identified future" Thus the study focus on taking the net present value for the future taxes and future transfers by a generation that are relevant. If generational accounts take care than the financial planning can be made for the long term and the control can be implement effectively.

$\mathrm{He}$ [4] tried find out the reason of the Uncontrollable spending of the Government in India. He mentions several factors such as poor organisation, functions and staffing of finance ministry that has resulted in financial mess. According to him many of the officers posted in the ministry are not with necessary skills and experience for all complex work of expenditure control and other financial priority areas. Further there are no systematic efforts to train them. The reason behind is favoritism. The appointments on such positions have little or nothing to do with candidate's expertise and his experience of such kind work rather it depends upon ministerial patronage. The government has never made a bold attempt for the maintaining the discipline in the departments which are indulging in fraud and corruption. Failure of Audit and lack of Legislative Interest in examining the budgets has also made the situation worst.

He [5] Explain the role of Public Financial Management System for those countries which are dependent on the Aids provided by the other (donor) countries. He also explain the good practice guidance and the principles which are relevant to Aid on Budget. Further he explain the role of AIMS i.e. Aid Information Management System according to which all the information and the database should be provided to donor country which can explain that how the funds are used by using the IT application in transparent manner. It helps to explain to them (donors) that the funds given by them has been utilised in the most appropriate manner for the welfare of the nation.

They [6] provided the approach which made clear distinction between the Public Expenditure Management and the Public Expenditure policy. According to them A Public Expenditure Policy try to answer the question that "What" is to be done where as Public Expenditure Management try to answer the question that "How" is to be done. They also said that the things required such as mechanisms, skills, technique and the data for the good Public Expenditure Management are totally different than those needed for formulating good policy. They further explain the eight important factors essential for well functioning of Public Financial Management System which are such as Good Regulated Institutional Framework, medium-term fiscal framework that put to use with certain methodological principles and standards, well defined budget preparation process, effective budget execution and monitoring, efficient accounting and reporting, regulated financial control, sound procurement systems and the budget management of EU (European Union) funds by EU member countries. They also define the importance of the role of World Bank, IMF, The organisation for economic corporation and Development (OECD) and European Union in Public Expenditure Management.

He [7] describe the Impact and Effectiveness of Transparency and Accountability Initiatives (TAIs) in Budget Process. The budget related Transparency and Accountability Initiatives are of various types and in different forms and relate to different phases of the budget process i.e. from planning stage of budget execution to audit and ex-post oversight. He also describe the role of Public Expenditure Tracking Surveys (PETS) in public expenditure management in the process of budget. He further explain how TAIs issues help to keep government honest and it also helps poor to focus and understand the policies made for their benefit. Not only this but TAIs also have the impact on taxation system and its governance on which any government rely heavily. 
They [8] describe the role of Budget Cycle in Public Financial Management. They classified the budget cycle in four different phases which are such as Budget Formulation, Budget Execution, Accounting and Reporting and External oversight. They further associate different aspect and actors which relates to each of these factors, which are such as budget preparation, capital budget, medium term expenditure frameworks, linking budgets to policy, programme and performance budget and cabinet ministry of finance, spending agencies legislature respectively.

\section{RESEARCH METHODOLOGY}

\subsection{OBJECTIVE OF THE STUDY}

The objective of the study is to make a comparative study of budgeted expenditure to actual expenditure of Haryana Budget in order to find out the accuracy of Haryana Budget in terms of expenditure forecasting. For this purposes the study considers Budgets and Actual of different types of expenditure such as Plan Expenditure, Non Plan Expenditure, Revenue Expenditure and Capital Expenditure.

\subsection{HYPOTHESES}

$\mathbf{H}_{01}$ : There is no significance difference between the Budgeted Non Plan Expenditure and Actual Non Plan Expenditure.

$\mathbf{H}_{\mathbf{0 2}}$ : There is no significance difference between the Budgeted Plan Expenditure and Actual Plan Expenditure.

$\mathbf{H}_{\mathbf{0 3}}$ : There is no significance difference between the Budgeted Revenue Expenditure and the Actual Revenue Expenditure.

$\mathbf{H}_{04}$ : There is no significance difference between the Budgeted Capital Expenditure and the Actual Capital Expenditure.

\subsection{TYPE OF DATA}

The current study is based on secondary data which is available at the official website of Haryana Government in forms of Budget at Glance [9]. Further the Expenditure (Non Plan, Plan, Revenue and Capital) are taken to compare the Budget and Actual of respective expenditure with each other for the purposes of analysis.

\subsection{PERIOD OF STUDY}

The present study takes the data for the period of 2006-07 to 2013-14.

\subsection{TOOLS AND TECHNIQUE}

The data has been analysed by using various statistical tool such as mean, standard deviation and Independent $\mathrm{t}$ test (two samples) with the help of SPSS.

\section{ANALYSIS}

\subsubsection{COMPARISON OF BUDGETED NON PLAN EXPENDITURE TO ACTUAL NON PLAN EXPENDITURE}

$\mathbf{H}_{01}$ : There is no significance difference between the Budgeted Non Plan Expenditure and Actual Non Plan Expenditure.

Fig. 4.1.2 GROUP STATISTICS (NON PLAN EXPENDITURE, RS IN CRORE)

\begin{tabular}{|ll|l|l|l|l|}
\hline & var00002 & n & mean & std. deviation & std. error mean \\
\hline var00001 & budget & 8 & 21304.5025 & 7266.59146 & 2569.12805 \\
& actual & 8 & 22006.1175 & 6574.00052 & 2324.26017 \\
\hline
\end{tabular}


Fig. 4.1.3 INDEPENDENT SAMPLE TEST (NON PLAN EXPENDITURE, RS IN CRORE)

\begin{tabular}{|l|l|l|l|l|l|l|l|}
\hline & \multicolumn{3}{|l|}{$\begin{array}{l}\text { levene's test for equality } \\
\text { of variances }\end{array}$} & \multicolumn{6}{l|}{ t-test for equality of means } \\
\cline { 2 - 8 } & $\mathrm{F}$ & sig. & $\mathrm{t}$ & $\mathrm{df}$ & $\begin{array}{l}\text { sig.(2- } \\
\text { tailed) }\end{array}$ & $\begin{array}{l}\text { mean } \\
\text { difference }\end{array}$ & $\begin{array}{l}\text { std. error } \\
\text { difference }\end{array}$ \\
\hline $\begin{array}{l}\text { equal variances } \\
\text { assumed }\end{array}$ & .059 & .812 & -.203 & 14 & .842 & -701.6150 & 3464.47749 \\
\hline
\end{tabular}

\subsubsection{RESULT}

The above statistics shows that the mean budgeted non plan expenditure was Rs 21304.5 crore while the mean actual non plan expenditure was Rs 22006.1 crore. The mean difference i.e. on an average actual expenditure over the budgeted expenditure was more than Rs700 crore. There is also high standard deviation within the budget and as well as in the actual i.e. of Rs 7266 crore and 6574 crore. However the calculated p value .842 which is more than the value of $\alpha=0.05$ shows that the null hypothesis is accepted. Thus there is no significant difference between budgeted and actual non plan expenditure.

\subsubsection{COMPARISON OF BUDGETED PLAN EXPENDITURE TO ACTUAL PLAN EXPENDITURE.}

$\mathbf{H}_{\mathbf{0 2}}$ : There is no significance difference between the Budgeted Plan Expenditure and Actual Plan Expenditure.

Fig. 4.2.2 GROUP STATISTICS (PLAN EXPENDITURE, RS IN CRORE)

\begin{tabular}{|c|c|c|c|c|c|}
\hline & var00002 & $\mathrm{N}$ & mean & std. deviation & std. error mean \\
\hline \multirow[t]{2}{*}{ var00001 } & budget & 8 & 11584.1350 & 5640.03727 & 1994.05430 \\
\hline & actual & 8 & 10354.8325 & 3685.57926 & 1303.04904 \\
\hline
\end{tabular}

Fig. 4.2.3 INDEPENDENT SAMPLE TEST (PLAN EXPENDITURE, RS IN CRORE)

\begin{tabular}{|l|l|l|l|l|l|l|l|l|}
\hline \multirow{2}{*}{} & \multicolumn{2}{|l|}{$\begin{array}{l}\text { levene's test for equality of } \\
\text { variances }\end{array}$} & \multicolumn{6}{l|}{ t-test for equality of means } \\
\cline { 2 - 8 } & $\mathrm{f}$ & sig. & $\mathrm{t}$ & $\mathrm{df}$ & $\begin{array}{l}\text { sig.(2- } \\
\text { tailed) }\end{array}$ & $\begin{array}{l}\text { mean } \\
\text { difference }\end{array}$ & $\begin{array}{l}\text { std. error } \\
\text { difference }\end{array}$ \\
\hline $\begin{array}{l}\text { equal variances } \\
\text { assumed }\end{array}$ & 1.451 & .248 & .516 & 14 & .614 & 1229.30250 & 2382.05570 \\
\hline
\end{tabular}

\subsubsection{RESULT}

The fig. no 4.2.2 and 4.2.3 shows that average of Budget of plan expenditure was Rs approximately 11584 crore while the average actual spending on account of plan expenditure was Rs. 10355 crore. Thus the actual expenditure incurred was less than budgeted expenditure averagely more than by Rs 1229 crore. However the calculated $\mathrm{p}$ value .614 which is more than the value of $\alpha$ taken at 0.05 shows that the null hypotheses is accepted. Thus there is no significant difference in the Budgeted and Actual Plan Expenditure.

\subsubsection{COMPARISON OF BUDGETED REVENUE EXPENDITURE TO ACTUAL REVENUE EXPENDITURE.}

$\mathbf{H}_{03}$ : There is no significance difference between the Budgeted Revenue Expenditure and the Actual Revenue Expenditure. 
Fig. 4.3.2 GROUP STATISTICS (REVENUE EXPENDITURE, RS IN CRORE)

\begin{tabular}{|ll|l|l|l|l|}
\hline & var00002 & n & mean & std. deviation & std. error mean \\
\hline var00001 & budget & 8 & 28263.2125 & 11338.00263 & 4008.58927 \\
& actual & 8 & 27494.3788 & 9385.10986 & 3318.13741 \\
\hline
\end{tabular}

Fig. 4.3.3 INDEPENDENT SAMPLE TEST (REVENUE EXPENDITURE, RS IN CRORE)

\begin{tabular}{|l|l|l|l|l|l|l|l|}
\hline & \multicolumn{4}{|l|}{$\begin{array}{l}\text { levene's test for equality of } \\
\text { variances }\end{array}$} & \multicolumn{5}{|l|}{ t-test for equality of means } \\
\cline { 2 - 8 } & $\mathrm{f}$ & sig. & $\mathrm{t}$ & $\mathrm{df}$ & $\begin{array}{l}\text { sig.(2- } \\
\text { tailed) }\end{array}$ & $\begin{array}{l}\text { mean } \\
\text { difference }\end{array}$ & $\begin{array}{l}\text { std. error } \\
\text { difference }\end{array}$ \\
\hline $\begin{array}{l}\text { equal variances } \\
\text { assumed }\end{array}$ & .292 & .597 & .148 & 14 & .885 & 768.83375 & 5203.73172 \\
\hline
\end{tabular}

\subsubsection{RESULT}

Fig. no 4.3.2 and 4.3.3 reveals that average of Budgeted and Actual Revenue Expenditure is Rs 28263 crore and 27494 crore respectively. The mean difference is about Rs. 769 crore. But the calculated p value is very high (.885) which is more than the value of $\alpha$ taken at 0.05 . Thus the null hypothesis is accepted. It communicates that the difference in the budgeted and actual revenue expenditure is not significant.

\subsubsection{COMPARISON OF BUDGETED CAPITAL EXPENDITURE TO ACTUAL CAPITAL EXPENDITURE.}

$\mathbf{H}_{\mathbf{0 4}}$ : There is no significance difference between the Budgeted Capital Expenditure and the Actual Capital Expenditure.

Fig. 4.4.2 GROUP STATISTICS (CAPITAL EXPENDITURE, RS IN CRORE)

\begin{tabular}{|cl|l|l|l|l|}
\hline var00002 & $\mathrm{n}$ & mean & std. deviation & std. error mean \\
\hline var00001 & Budget & 8 & 4625.4250 & 1673.44213 & 591.65114 \\
& Actual & 8 & 4869.0713 & 1261.62943 & 446.05336 \\
\hline
\end{tabular}

Fig. 4.4.3 INDEPENDENT SAMPLE TEST (CAPITAL EXPENDITURE, RS IN CRORE)

\begin{tabular}{|l|l|l|l|l|l|l|l|}
\hline \multirow{2}{*}{} & \multicolumn{4}{|l|}{$\begin{array}{l}\text { levene's test for equality } \\
\text { of variances }\end{array}$} & \multicolumn{5}{l|}{ t-test for equality of means } \\
\cline { 2 - 8 } & $\mathrm{f}$ & sig. & $\mathrm{t}$ & $\mathrm{df}$ & $\begin{array}{l}\text { sig.(2- } \\
\text { tailed) }\end{array}$ & $\begin{array}{l}\text { mean } \\
\text { difference }\end{array}$ & $\begin{array}{l}\text { std. error } \\
\text { difference }\end{array}$ \\
\hline $\begin{array}{l}\text { equal variances } \\
\text { assumed }\end{array}$ & 1.123 & .307 & -.329 & 14 & .747 & -243.64625 & 740.95524 \\
\hline
\end{tabular}

\subsubsection{RESULT}

The above statistics revels that on an average the budget of capital expenditure was Rs 4625 crore. However the actual average spending on the same was Rs 4869 crore. The mean difference was about Rs 243 crore. But again the calculated $\mathrm{p}$ value is very high (.747) and more than the value of $\alpha=0.05$. It shows that the null hypothesis is accepted and thus the difference between the budget and actual of capital expenditure is not a significant difference.

\section{CONCLUSION}

As it was asked above the Budgets are forecasted for the future and future is uncertain. Thus it (Budget) never can be forecast with 100 per cent accuracy but it is always expected to have some good amount of accuracy otherwise the role of Public Budgets will be nil. Our results also shows that there was always difference between the budgeted and the actual expenditure whether non plan, plan, capital or revenue expenditure. But the t-statistics explained that these difference are not significant subject to $\alpha=0.05$ which is necessary to take to provide the 
margin of error. Thus we can conclude that the budgets of the expenditures were made efficiently in all the cases whether it is non plan, plan, revenue or capital expenditure.

\section{REFERENCES}

[1] Budget Speech, Capt. Abhimany, Finance Minister, Haryana http://web1.hry.nic.in/budget/Glance/FMSpeechenglish.pdf

[2] Woska William J.(Jan.-Feb .1998), Pay for Time Not Worked: A Public- Sector Budget Dilemma, Public Administration Review, Vol. 48, No. 1, pp. 551-556 http://www.jstor.org/stable/975518

[3] Haveman Robert (1994), Should Generational Accounts Replace Public Budget and Deficits?, The Journal of Economic Perspectives, Vol. 8, No. 1, pp. 95-111, http://www.jstor.org/stable/2138153

[4] Joseph K.P.(Jan 1996), Why Government Spending is out of Control, Economic and Political Weekly, Vol. 31, No. 4, pp. 192-194, http://www.jstor.org/stable/4403705

[5] Carter Rebecca (March 2008), Putting Aid on Budget, A Study for the Collaborative Africa Budget Reform Initiative (CABRI) and the Strategic Partnership with Africa (SPA), Mokoro Ltd., pp 2-42.

[6] Djurovic-Todorovic Jadranka, Djordjevic Marina (December 2009), The Importance Of Public Expenditure Management In Modern Budget System, Economics and Organization, Vol. 6, No 3, pp. 281 to 294.

[7] Carlitz Ruth (2010), The Impact and Effectiveness of Transparency and Accountability Initiatives: A review of the evidence to date, Budget processes, Annex-2, Institute of Development Studies, pp 4-28.

[8] Simson Rebecca, Sharma Natasha \& Aziz Imran (December 2011), A guide to public financial management literature, Overseas Development Institute, pp 2-18.

[9] Budget (Haryana) at http://web1.hry.nic.in/budget/Archives/Archive.html 